\title{
Колеравы код традыџыйнай культуры вачыма фалькларыста
}

Іна Швед, Міфалогія колеру ў беларускай традыцыйнай духоўнай культуpbl, Брэст 2011, сс. 291

Швед Іна Анатольеўна ў рэцэнзаванай манаграфіi робіць першую ў беларускай фалькларыстыцы спробу рэканструкцы колеравага коду беларускай традыцыйнай духоўнай культуры. Дадзены код даследуецца ва ўсім багацці яго характарыстык, паўнаце яго ўнутраных і знешніх сувязяў і адносін. Пры гэтым аўтар сыходзіць са слушнага меркавання, што вывучэнне паасобных колеравых сімвалаў па-за рамкамі кода, у межах якога яны функцьянуюць, i часта па-за кантэкстам знакава-сімвалічнай сістэмы традыџыйнай культурьи, без гльбокай рэканструкцыі міфапаэтычнай мадэлі свету не дазваляла ўсебакова раскрыць сутнасць фальклорных сімвалаў, вызначьць спецьфіку міфалогіi колеру, як $і$ міфалогіi іншых фрагментаў традыцыйнай кариінь свету беларусаў (с. 81) і што глыбіннае значэнне семіятызаваных колераў магчыма выляіџь толькі пры звароче да знешніх у адносінах да іх "крыніи" (рытуал, міфалогія, вусная паэзія, мова), прь ўключэнні ў якія колер набьвае (актуалізуе) статус знака, сімвала; міфалогію колераў, самья архаічныля элементы іх сімволікі раскрываючь вераванні і абрадавы матэрыял (с. 262).

11 Гл.: Мушынскі М. І., Летапіс жыция $і$ творчасиі Якуба Коласа, Мінск 2012. 
Актуальнасць такога падыходу не выклікае сумненняў. Спалучэнне апісальнага падыходу з парадыгматычным дало магчымасць аўтару ўпершыню на беларускім матэрыяле выявіць спецыфіку семантыкі і функцыянальнасці асноўных колеравых сімвалаў і адначасова дыяд і трыяд, якія яны ўтвараюць у пэўных фальклорных тэкстах. Рэтра-рэфлексія ўсіх актуалізацый колеравых сімвалай дазволіла апісаць "алфавіт" колеравага кода, яго структурную, семантычную і "стылістычную" арганізацыю.

У першым раздзеле "Колеравы код культуры як праблема міждысцыплінарнага даследавання" Іна Анатольеўна абагульніла шырокае кола неабходнай класічнай і найноўшай літаратуры (у прыватнасці, важныя з пункту гледжання тэорыі і метадалогіi даследавання знакава-сімвалічнай сферы традыцыйнай культуры славян работы супрацойнікаў Інстытута славяназнаўства РАН; г. Масква), пры выпрацоўцы свайго падыходу да прадмета даследавання, вызначэнні тэарэтыка-метадалагічных асноў даследавання колеравага кода беларускай традыцыйнай культуры прадуктыўна выкарыстала набыткі айчынных і замежных гуманітарыяў у сферы вывучэння колеру як чынніка культуры, матэрыялы слойнікаў “Славянские древности" (Масква 1999-2009, т. 1-4), "Беларуская міфалогія" (Мінск 2011), "Беларускі фальклор" (Мінск 2005-2006, т. 1-2) і інш.

У цэнтры разгляданага даследавання знаходзяцца вызначальныя элементы колеравага коду беларускай традыцыйнай духойнай культуры - белы, чырвоны, чорны (так званая ўніверсальная колеравая трыяда), жоўты, зялёны, сіні і шэры колеры, якім прысвечаны асобныя раздзелы другой главы. У першым з іх аўтарка слушна сцвердзіла, што пазітыўна ацэнены белы колер асацыюецца з жыццёвай сілай, вытворчай патэнцыяй, якая знаходзіцца ў яйку, малацэ і мужчынскім семені, і суадносіцца з кардынальнымі канцэптамі пачатку (што выразна выяўлена у у ініцыяцыйных, прадуцыравальных і ачышчальных рытуалах). Разам з тым на міфалагічным узройні беламу колеру можа надавацца семантыка пустаты, безжыццёвасці, бесцялеснасці, што адсылае да канцэптаў «смерць» і «нецнатлівасць» (у вясельным абрадзе). Белы абазначае нараджэнне новага і адначасова растварэнне, знікненне старога. Калі сімволіка белага колеру вызначаецца яго асацыяцыяй з пустатой, бесцялеснасцю, смерцю, ён выступае ў аднолькавых абрадавых сітуацыях і міфапаэтычных кантэкстах з чорным, сінім і жоўтым колерамі і можа ўтвараць апазіцыйныя адносіны з чырвоным колерам. Між тым усе гэтыя колеры могуць выступаць прыкметай не-чалавечай (часта дэманічнай) прыроды разнастайных персанажаў і фігураваць у каляндарных і сямейных абрадах з пераапрананнем.

У другім раздзеле, прысвечаным міфалогіі чырвонага колеру, паказана, што, з аднаго боку, гэты колер асацыюецца з субстанцыяй жыцця - крывёй, а таксама жаночымі атрыбутамі і сімвалізуе плоднасць, узнаўленне, здаройе (чырвоны, у адрозненне ад жоўтага, сіняга, белага (= бледнага), зялёнага, чорнага, шэрага, - індыкатар здароўя), дынамічны пачатак, любоўную моц, багацце, шчасце, знаёмства, выяўляе прынцыпы тварэння, актыўнасці, развіцця, надзяляецца прадуцыравальнымі, гаючымі і апатрапейнымі ўласцівасцямі. У песнях на любоўна-шлюбную тэматыку (у першую чаргу вясельных) і нека- 
торых іншых чырвоны колер, акрамя таго што надзяляецца прадуцыравальнай сімволікай, у агульным плане станоўча характарызуе вылучаныя асобы, прадметы, з'явы, абазначае заключную фазу дзявочага росту, гатоўнасць дзяўчыны да шлюбу, сімвалізуе любойна-эратычныя адносіны. 3 другога боку, чырвоны колер асацыюецца з крывавай небяспекай, парушэннем гармоніi, далучанасцю да іншасвету, лімінальнасцю (у абрадах жыццёвага цыкла чырвоныя прадметы не толькі выконваюць ахойную функцыю, але і абазначаюць пераходны стан іх аб'ектаў: немаўляці, жаніха і нявесты, нябожчыка). Можна пагадзіцца з заключэннем Іны Анатольеўны, што чьлвоны колер вызначаециа семантыкай смериі і функиьяй яе пераадолення (с. 156).

Чорны колер, паводле аўтарскіх назіранняў, вызначаецца асаблівым міфалагічным статусам у народнай культуры які мае магічныля, рытууальныля функцыі і сімвалічныл характарыстыкі - у параўнанні з іншылі колерамі, пастаянныля, найбольш канкрэтныля (с. 157). Пры гэтым I. А. Швед падкрэслівае, што чорны суадносіцца з ноччу, са сном, адсутнасцю свядомасці, радасці, развіцця, з распадам, завяршэннем цыкла, зямлёй, падзем'ем і да т.п. Разам $з$ тым асаблівы міфалагічны статус чорнага колеру ў многім тлумачыць разгалінаванасць павер'яў пра вызначанасць рэалій гэтага колеру. Чорны колер шырока прадстаўлены ў магічных рытуалах, звязаных са смерцю (рэальнай ці сімвалічнай), заканчэннем ці перарываннем пэўнага этапу існавання, актыўным умяшальніцтвам у жыццё чалавека знешніх дэструктыўных сіл. Чорны сімвалічна выяўляе безжыццёвасць, нябачнасць (у прыватнасці нябачнасць таго свету для жывых людзей), небыццё, спыненне камунікацыі, хаос, разбурэнне, небяспеку для здароўя і жыцця чалавека, не-чалавечае, няправеднае, злое, агрэсіӱнае і маркіруе пэўны аб'ект як прыналежны да таго свету, чужы, грахойны, падкрэслівае магічныя ці дэманічныя ўласцівасці персанажа, недвухсэнсойна ўказвае на яго варожае стаўленне да людзей, іх маёмасці і да т.п. Пагодзімся з думкай аўтара, што на фоне таго, што чорнае трактуециа як нячьстае, бруднае, выяўляе функцьянальную $і$ семантычную сувязь з тым светам, выступае магічным засяроджаннем хтанічнай існасиі, становічиа зразумельм прыпісванне чорнаму колеру (рэаліям, ім маркіраваным) апатрапейна-засцерагальных уласчівасчей, функиый страшання, выкарыстанне яго як сродку пераадолення крытычнай сітуачьі, магічнага праграмавання руху нячьстай сіль вонкі з чалавечага свету. Чорны сімвалічна асацыюециа са спараджальна-хтанічным Касмічным нізам, а таму можа інтэрпрэтавачча як засяроджанне энергіi эратычнай, магічнай, чарадзейнай. На асацьлтыьўнай сувязі чорнага колеру з зямлёй $і$ ўраджаем, спельм семенем, якія яна родзіџь, засноўваечиа семіятызачыя чорнага колеру як знака плоднасці, багачия. Праз сімволіку чорнага колеру ў мібапаэтычнай мадэлі свету беларусаў маркіруециа час і прастора (с. 188).

Выклад матэрыялу адносна міфалогіі жойтага колеру дазваляе I. А. Швед прыйсці да слушнага заключэння, што яго амбівалентная семантыка ўключае (у залежнасці ад кантэксту) матывы агню, сонечнага святла, золата, плоднасці, матэрыяльнага багацця, высокага сакральнага статусу; жоўтыя косы - дзявочы эстэтычны ідэал. Жоўты колер шырока прадстаўлены ў магічных актах прафілактыкі і лячэння хвароб - паводле сімптомаў, звязаных 
3 ім. Але пераважна жойтае мае негатыўную ацэнку, кадзіруе ўяўленні пра чужое, анамальнае, сімвалізуе далучанасць да замагільнага свету, пераходны стан, атаясамліваецца 3 хваробай, смерцю, звязваецца з прынцыпамі разбурэння, знікнення вітальных сіл. Гэтыя ўяўленні канцэнтруюцца вакол пераходных абрадаў і перыядаў, калі чалавек знаходзіцца у асобым з пазіцыі народнага светапогляду стане. Негатыўная семантыка жойтага ўзмацняецца у народных тлумачэннях сноў, у якіх яно трактуецца як знак няшчасця, расстання, здрады.

Як амбівалентны і полівалентны сімвал разгледжаны у манаграфіі і зялёны колер. Падкрэслена, што як галоўны тон лета зялёны - гэта колер поўнай жыццёвых сіл расліннасці, прыроды ў яе зменлівасці, няспеласці, маладосці, які выяўляе актыўнасць, стварэнне, жыццястойкасць, сімвалічна звязваецца 3 развіццём, пераходнасцю. 3 іншага боку, пры асацыяцыях з пасіӱнасцю, нерухомасцю, хтанізмам (расліннасць выходзіць з-пад зямлі), зялёны колер судачыняецца са сферай смерці, сімвалізуе безжыццёвасць, той свет і яго прадстаўнікоў, а таксама нязменнасць (зялёныя плесень, ціна). І. А. Швед слушна сцвярджае, што гэтыя факты вызначаюць багацце міфа-абрадавых кантэкстаў зялёнага колеру ў беларускай традыцыйнай культуры. Праведзены аналіз фальклорна-этнаграфічнага матэрыялу дае магчымасць сцвярджаць, што зялёны ўжываецца у характарыстыках адмоўных персанажаў са значэннямі 'хворы', 'нерухомы', 'сумны', 'сапсаваны'; разам з тым выкарыстойваецца пры апісанні ўдзельнікаў вясельнага і радзіннага рытуалаў, каханага мужчыны ці жанчыны са значэннямі 'малады', 'прыгожы', 'святочны', 'лепшы', 'дарагі'.

Што да сіняга колеру, то, як паказана на матэрыяле розных відаў і жанраў беларускай традыцыйнай духоўнай культуры, ён маркіруецца часцей негатыўнымі канатацыямі, з'яўляецца атрыбутам хтанічнага і дэманічнага свету і яго прадстаўнікоў. Ён таксама асацыюецца з мужчынскім пачаткам, выступае прыкметай неба, мора, нябеснага і падземнага агню (у прыватнасці з'яўляецца эпітэтам сонечнага ззяння, маланкі, падземных скарбай), асацыюецца з серабром, поўнай жыццёвых сокаў расліннасцю, а ў некаторых выпадках - з аднесенымі да чужога свету лозамі і асінай. У вертыкальнай трох'яруснай будове свету сінім колерам характарызуюцца маркёр сярэдняга яруса - дуб, а таксама камень, які звычайна цэнтруе той свет. Маркіроўка локусаў як сініх (нават калі эпітэт «сіні» функцыянуе у якасці пастаяннага - сіняе мора, сіняе неба) указвае на іх аддаленасць ад свету чалавечага, далучанасць да свету чужога. Для народнай дэманалогіi, як слушна адзначае аўтар, характэрна супадзенне сімвалічных прыкмет сіняга, зялёнага і чорнага.

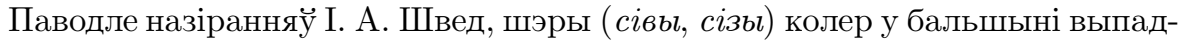
каў служыць індыкацыі адмоўных або нейтральных з'яў, выяўляе маргінальны статус пазначанага ім аб'екта, далучанасць істоты да замагільнага свету, прэзентуе канцэпт чужога, ідэю пераходу (з адной сферы светабудовы ў другую, у новую форму існавання, з аднаго стану ў іншы), атрыбутуе розныя рэаліі, надзеленыя семантыкай зменлівасці, маркіруе дэманічных істот і сакралізаваных жывёл-медыятараў са здатнасцю пранікаць у іншы свет. Гэты колер прадстаўлены ў магічных рытуалах, якія звязаны з заканчэннем ці пера- 
рываннем пэўнага этапу існавання, са спыненнем актыўнага ўмяшальніцтва у жыццё чалавека знешніх дэструктыўных сіл. Сімвалічная функцыя шэрага колеру як пасрэдніка матываваная тым, што ў ім злучаюцца два процілеглыя прынцыпы: прынцып белага і прынцып чорнага. Магчыма, таму шэры абазначае няяснасць, нявызначанасць, туманнасць, змешанасць, між тым у гэтай невычэрпнай змешанасці (як у гліне) прыхаваныя розныя рэчы і формы. Аўтар выказвае меркаванне, што магчьлм таму шэрыля жывёль-медылтары надзяляюица высокай дзейснасцю (с. 237). Асаблівую цікавасць выклікаюць пададзеныя у с спецыяльным раздзеле назіранне і аналіз важнейшых асаблівасцяй функцыянавання колеравых дыяд і трыяд у беларускім фальклоры.

Завяршаючы свае выклады, Іна Анатольеўна звяртае ӱвагу на тое, што разгледжаныя чыннікі колеравага коду як арганізуючыя фактары традыцыйнай храматычнай камунікацыі захавалі сувязь з архетыпавылі ўяўленнямі i разам з тылм сталі адмьсловылі эталонамі, пры дапамозе якіх фіксавалася ідэальная мадэль адносін у сістэмах «чалавек - прырода», «чалавек сочьум», $i$ адпаведна структуравалася $i$ арганізоўвалася чалавечая дзейнасць (с. 252 ). У манаграфіі паказана, што названыя колеры з'яўляюцца грунтам семантычных апазіцый тыпу «белы/чорны», «жоўты/чырвоны», «белы/чырвоны», маркёрамі класаў ізафункцыянальных аб'ектаў і могуць кваліфікавацца як прыкметы, што выступаюць важным інструментам асэнсавання і ментальнай арганізацыі рэальнасці міфапаэтычным мысленнем у рамках усеахопнай антытэзы Хаос - Космас. Пагодзімся з аўтарам і ў тым, што прадметнае поле колеравых прыкмет у фальклоры надзвычай шырокае, а ix культурная трактойка ўцягвае у семантычную сферу пэўных колерай шырокі спектр асацыяцый, канатацый, матываў; колеравыя прыкметы вельмі часта кладуцца ў аснову семантычнай матывіроўкі назваў розных рэалій. Даследчыца на прэзентатыўным матэрыяле даводзіць, што у беларускім фальклоры колер характарызуе станы, уласцівасці, аб'екты, з'явы, дзеянні, чалавека, прадметы, паняцці; маркіруе не-чалавечы свет і яго прадстаўнікой; выступае элементам намінацыі людзей, раслін, жывёл, прыродна-ландшафтных аб'ектаў, дэманічных істот. Колеры не толькі аказваюцца матэрыялам для пабудовы культурных мадэляў з няколеравым зместам, адыгрываюць ролю важных класіфікатараў, у дэманалогіі з'яўляюцца прыкметамі, на аснове якіх розныя катэгорыі дэманічных персанажаў можна адрозніць ад рэальна існуючых людзей, жывёл ці артэфактаў, але і выконваюць ацэначную ролю, вызначаюць чалавека ў яго біялагічным, сацыяльным, рытуальным статусах. Паказана таксама, што колеравыя характарыстыкі становяцца адным з вызначальных элементаў у раскрыцці міфалагічнай сімволікі часавых адрэзкаў, якія праз колеравую прыкмету атрымліваюць больш глыбокую і адэкватную інтэрпрэтацыю. Так, вылучаныя ў каляндарна-часавай прасторы т.зв. чьлрвоныля, чорныля $i$ бельля днi (тылні), акцэнтуюць пачатак (ці канец) пэўных перыядаў і адпаведна ацэньваюць іх (такія словазлучэнні намініруюць не толькі перыяд, але і ўказваюць на стан).

Разгледжаны ў манаграфіi матэрыял робіць відавочнай і важнасць колераў як семантычных катэгорый у каляндарных, сямейных і аказіянальных абрадах, многія з якіх, як сведчаць шматлікія апісанні, літаральна насычаны 
колерам; пры гэтым колеравая прыкмета перадаецца праз прадстаўленне вызначанага традыцыяй прадмета - яе носьбіта (вопратка, аксесуары, прадметны рад і інш.). Асноўныя ідэі і мэты рытуалаў (дэкларацыя пераходу ў новыя сацыяльны, біялагічны станы, замацаванне новага статуса, прадуцыраванне дабрабыту, ахова, кампенсацыя, пакрыццё пэўнага дэфіцыту, трансляцыя інфармацыі пра псіха-фізічны, сацыяльны, матэрыяльны станы ўдзельнікаў рытуалу, вырашэнне задач полавай ініцыяцыі, выяўленне эстэтычных, эмацыянальных і іншых ацэнак (колер як знак здаровага/нездаровага, прыгожага/непрыгожага, багатага/беднага, высокага/нізкага сацыяльнага статуса і г.д.), як адзначае I. А. Швед, рэалізуюцца таксама праз актуалізацыю каларыстычнага «слоўніка» вербальнай складаючай абрадавых комплексаў. У вербальных тэкстах называнне прадмета, які характарызуециа вызначаным колерам, адпавядае прэзентацыі колеравай прыкметы прадмета для перадачы пэўнага значэння ў рытуале. Натуральна, што калі колеравы код прадстаўлень ў рытуале імплічьтна, праз прэзентацью прадметаў, для якіх колеравая прькмета выступае адной з шэрагу сімвалічных, названы код абавязкова знаходзічиа ва уัзаемадапаўняльных адносінах з іншымі: персанажным, расліннылм, жывеёльнылм, рэчавьлм, рэчьйнылм і інш. (с. 263).

Вынікам аналізу шырокага фонду фальклорна-міфалагічных тэкстаў (у семіятычным значэнні) з прымяненнем сучасных методыкі і ведаў у галіне фалькларыстыкі, міфалогіi, светапогляднай архаікі, колеразнаўства і інш. стала ўсведамленне таго, што колеравы код да сённяшняга часу захойвае сваю культурную актыўнасць, выяўляе здатнасць назапашваць інфармацыю, г.зн. здатнасць памяці, і функцыянаваць як самакаштоўная форма міфа-фальклорнага сама- і светавыяўлення, як прыродна-культурны і эстэтыка-камунікатыўны феномен, праз які артыкулюецца складаны комплекс народных уяўленняў. Колер у беларускай традыцыйнай культуры, як слушна даводзіць I. А. Швед, працягвае выконваць інтэрпрэтатыўную і рэгулятыўную (аксіялагічную, гнасеалагічную, мемарыяльную, прагматычную, у тым ліку магічную) функцыі.

Асабліва хочацца падкрэсліць, што манаграфія "Міфалогія колеру ў беларускай традыцыйнай духоўнай культуры" напісана на аснове ўласных аўтарскіх рэканструкцый семантыкі, сімволікі і прагматыкі колеравых сімвалаў, наяўных у фальклорных тэкстах. Значную частку матэрыялу, уведзенага ў яе змест, складаюць уласныя запісы аўтара, якія захоўваюцца ў архіве вучэбнай фальклорна-краязнаўчай лабараторы БрДУ імя А. С. Пушкіна і якія ў пэўнай ступені паглыбляюць сучасныя навуковыя веды пра сутнасць колеравага коду беларускага традыцыйнай культуры.

У заключэнне азначым, што манаграфія I. А. Швед - самастойная і арыгінальная навукова-даследчая праца, якая арганічна ўпісваецца ў парадыгму гуманітарных даследаванняў пачатку XXI ст. Яе матэрыялы карысныя для навуковых работнікаў (фалькларыстай, этнолагаў, этналінгвістай), выкладчыкаў, студэнтаў, аспірантаў. ЁСЦЬ СПАДЗЯВАННЕ, ШТО Асэнсаванне праблем міфалогіі колеру, функцыянавання колеравага кода беларускага фальклору дасць магчымасць пашырыць навуковыя пошукі на сістэмы іншых кодаў, вывучэнне міфалогіі іншых чыннікаў народнай карціны свету беларусаў. Выні- 
кі працы дазволяць выявіць агульныя і адметныя інфарматыўныя зоны для розных кодаў; стварыць метасістэму знакавага адлюстравання касмалагічных, анталагічных, сацыяльных уяўленняў нашых продкаў, на высокім навукова-тэарэтычным узроўні распрацаваць канцэпцыю развіцця нацыянальнага мастацтва з улікам эстэтычных прыярытэтаў беларусай.

Тацияна Валодзіна Мінск 